\title{
Design of a Co-Digestion Biogas Plant to Curb Deforestation-Case Study of Phalombe Secondary School in Malawi
}

\author{
Nyirenda Austin Kawelamzenje ${ }^{1,2}$, Maurice Twizerimana ${ }^{1,3,4 *}$, Dushengere Bernadette ${ }^{5,6}$, \\ Alexis Bakundukize ${ }^{1}$ \\ ${ }^{1}$ African Centre of Excellence in Energy for Sustainable Development (ACE-ESD), College of Science and Technology, University \\ of Rwanda, Kigali, Rwanda \\ ${ }^{2}$ Malawi University of Science and Technology, Limbe, Malawi \\ ${ }^{3}$ Department of Manufacturing, Industrial and Textile Engineering, School of Engineering, Moi University, Eldoret, Kenya \\ ${ }^{4}$ Africa Centre of Excellence II in Phytochemicals, Textiles and Renewable Energy (ACE II PTRE), Moi University, Eldoret, Kenya \\ ${ }^{5}$ Department of Mechanical and Production Engineering, School of Engineering, Moi University, Eldoret, Kenya \\ ${ }^{6}$ Mobility for Innovative Renewable Energy Technologies (MIRET), Moi University, Eldoret, Kenya \\ Email: *twizerimanamaurice@gmail.com
}

How to cite this paper: Kawelamzenje, N.A., Twizerimana, M., Bernadette, D. and Bakundukize, A. (2021) Design of a Co-Digestion Biogas Plant to Curb DeforestationCase Study of Phalombe Secondary School in Malawi. Open Access Library Journal, 8: e7255.

https://doi.org/10.4236/oalib.1107255

Received: February 15, 2021

Accepted: March 28, 2021

Published: March 31, 2021

Copyright (C) 2021 by author(s) and Open Access Library Inc.

This work is licensed under the Creative Commons Attribution International License (CC BY 4.0).

http://creativecommons.org/licenses/by/4.0/

\begin{abstract}
Biogas technology is one of the renewable technologies that use biodegradable waste such as human waste (HW), agricultural waste, animal and food waste. Over $90 \%$ of the population in Malawi is heavily reliant on firewood as their primary source of energy for cooking. This results in deforestation, pollution of the environment, and great monetary expenditure to buy firewood, more especially by boarding schools. A co-digestion biogas plant that uses human, animal, agriculture, and canteen food waste has been designed. This study design was based on the use of HW and canteen food wastes (CFW) as the substrate for the biodigester to produce methane $\left(\mathrm{CH}_{4}\right)$ gas that could be used for cooking and lighting at Phalombe Secondary School in Malawi to replace firewood. With a school population of 757 people, design calculations/stimations were performed to find out the amount of HW and CFW required per day. A field survey at the school was carried out to appreciate the problem the school is facing so that a solution could be found. Based on factors such as energy demand at the school, availability of feedstock, size of the digester, biogas yield, life span of the biodigester, and availability of construction materials, the type of biogas plant suitable for this purpose has been selected and designed. A computer-aided design (Auto CAD) software was used for the drawing. These design parameters were arrived at through a baseline survey, observation methods, and literature reviews. Through a questionnaire, a detailed energy demand analysis was carried out from whose results a fixed
\end{abstract}


dome biogas plant of digester size $62 \mathrm{~m}^{3}$, gasometer of size $19 \mathrm{~m}^{3}$, and digestate collection tank size of $61 \mathrm{~m}^{3}$ has been designed. The design came up with an amount of HW and CFW of 286 and $60 \mathrm{~kg}$ per day respectively making total organic raw materials of $346 \mathrm{~kg}$ per day. The macromolecular composition of the HW, CFW, and mixture of HW and CFW in terms of dry matter (DM) was $11 \%, 45 \%$ and $56 \%$ of carbohydrate, $3 \%, 15 \%$, and $18 \%$ of protein, $15 \%, 40 \%$, and $30 \%$ lipids, and $15 \%, 0 \%$, and $15 \%$ of ash respectively. The substrate showed a high degradability of $90 \%$. The simulation analysis showed that HW produced $185 \mathrm{~m}^{3}$ per $\mathrm{kg}$ of biogas which represented $64 \%$ and $35.9 \% \mathrm{CH}_{4}$ and carbon dioxide $\left(\mathrm{CO}_{2}\right)$, CFW produced $58.9 \mathrm{~m}^{3}$ per $\mathrm{kg}$ that represented $61.1 \%$ and $38.4 \%$ of $\mathrm{CH}_{4}$ ad $\mathrm{CO}_{2}$, and mixture produced $265 \mathrm{~m}^{3}$ per $\mathrm{kg}$ contained $59 \%$ and $41 \%$ of $\mathrm{CH}_{4}$ and $\mathrm{CO}_{2}$ in 40 days respectively. A cost estimate of the design has been carried out to appreciate the economic viability of the biogas technology and is estimated at the US $\$ 5277$. The cost of constructing a biogas plant at the school is less than what the school is spending currently on firewood and electricity, a recommendation has been made to adopt the technology to reduce the financial burden the school is facing.

\section{Subject Areas}

Renewable

\section{Keywords}

Biodigester, Co-Digestion, Phalombe, Human Waste, Curb Deforestation

\section{Introduction}

Biogas has been used in most parts of the world for cooking, heating, and lighting. In Africa, countries such as Kenya, Uganda, Ethiopia, Tanzania, Rwanda, Cameroon, Burkina Faso, and Benin have benefited from this technology through National Biogas programs initiated by their governments [1]. In Malawi, little has been done to promote this technology. Since access to electricity is still very low (10.8\% in 2018 and projected to $12.7 \%$ in 2020) [2] [3]. Malawi's main source of energy for cooking is firewood. Over $90 \%$ of the population in Malawi is heavily reliant on firewood as their primary source of energy for cooking. Most boarding secondary schools in Malawi depend on firewood as their main source of energy for cooking and heating water. This results in deforestation, pollution of the environment, and great monetary expenditure to buy firewood, more especially by boarding schools. Moreover, this places a financial burden on these schools due to the ever-increasing prices of firewood. One amongst such schools is Phalombe Boarding Secondary School. It is against this background that it was proposed to design a co-digestion biogas plant for use at Phalombe Boarding Secondary School. To generate more biogas, the temperature in the biodigester must be increased [4]. Methane-producing bacteria will operate most efficiently if temperatures in the biodigester are in the range of 
$30^{\circ} \mathrm{C}-40^{\circ} \mathrm{C}$ for the mesophilic bacterial activity and $50^{\circ} \mathrm{C}-60^{\circ} \mathrm{C}$ for the thermophilic bacterial activity [5]. The thermophilic temperature is responsible for methane production and is reached after a longer HRT (40 - 60 days). A longer HRT is favourable for the production of more methane gas than a shorter HRT which produces more hydrogen gas than methane [6]. A pH of 7.8 to 8.2 is preferred for methanogenic bacteria to digest the waste for the production of methane gas [7]. It is against this background that the simulation used a temperature of $55^{\circ} \mathrm{C}$ and $\mathrm{pH}$ of 7.8 (neutral) to calculate biogas production.

Phalombe district is located in a moderate to hot zone which has very good weather conditions for biogas production. Its monthly temperatures ranging from $25^{\circ} \mathrm{C}$ to $28^{\circ} \mathrm{C}$ but temperatures of more than $30^{\circ} \mathrm{C}$ are obtained in the hot summer season. The school enrolls 562 students and has around 195 members of staff including their dependents. This brings to a total number of 757 people. This number of people is enough to produce the human waste (HW) necessary to sustain the project. Furthermore, there are always a lot of food leftovers at the students' canteen which can be used to co-digest with HW. The school is surrounded by three villages that are engaged in agricultural activities such as cattle and rice farming; from which we can also obtain daily feeding materials for this biogas plant. This biogas plant will use HW and canteen food wastes (CFW). To supplement these daily feeding materials, it will also use cow manure and agricultural wastes such as rice bran from the surrounding villages. Once the plant is installed at the school, it will curb deforestation and reduce the amount of money the school spends on cooking and lighting. Biogas offers a great alternative for fuel for cooking, heating, and lighting. It also addresses the issues of HW disposal [8]. It reduces the impacts on the environment which are mostly caused by deforestation and greenhouse gas emissions into the atmosphere. Biogas is a combustible mixture of gases that primarily consists of Methane $\left(\mathrm{CH}_{4}\right)$, Carbon dioxide $\left(\mathrm{CO}_{2}\right)$, and other trace elements [9] [10]. These gases are produced from the decomposition of organic wastes through anaerobic digestion (AD) [11]. There are several designs of biogas plants across the world and the designs depend on geographical location, availability of substrate, and climatic conditions [12]. Some biogas plants are fixed underground while others are constructed above the ground. Out of the different biogas digesters, the fixed dome model developed by China and the floating drum model developed by India has continued to perform well until today [1] [13].

The size of the digesters depends on the location, the number of households, and the amount of substrate available every day. Biogas plant models can be modified to suit the conditions of Malawi and Phalombe Secondary School in particular. This research is therefore aimed at seeking to modify the available performing biogas designs in Malawi that only use one type of substrate for digestion. The designed biogas plant will make use of HW and CFW to co-digest them to produce biogas for cooking and lighting at the school to replace firewood. Mzuzu University in Malawi under the faculty of Renewable Energy has been implementing fixed dome biogas projects in rural areas of Malawi using 
sing digestion to preserve the carbon sink and switch to a cleaner and more efficient alternative to firewood. One of the beneficiaries of this project is Ruguwa Mhlanga Village, a rural village North East of Mzuzu [1]. Similarly, tubular polyethylene biogas digesters have been developed and tested in Zomba in Malawi by the Swedish University of Agricultural Sciences in conjunction with the University of Malawi (Chancellor College) to cut back deforestation and support global climate change mitigation and adaptation. Waste management and agricultural productivity can even be improved as a result of biogas technology. Further, the event and promotion of biogas within the energy sector can propel the establishment of the latest enterprises thereby creating a full range of opportunities for jobs and tiny and medium enterprises both in urban and rural areas [13].

With all the advantages above in mind, the construction of a biogas plant at Phalombe Boarding Secondary School will be very vital. The biogas plant will use HW from school toilets and CFW from student's canteen as feedstock (substrate) for co-digestion. The biogas plants that are currently in use in Malawi use single digestion (only one type of feedstock). This research study aims at addressing this gap by introducing co-digestion. To supplement the feedstock, it will also be using animal manure and crop residues such as rice straw/bran from the surrounding communities. Phalombe is one of the highest rice-producing districts in Malawi but does not make use of rice bran after rice milling. Millions of tons of rice bran are not used and are either burned into ashes or just thrown away. The district is also engaged in animal farming which includes goats, cows, and pigs. From these farm animals, farm manure can be collected and used as a daily feeding material/feedstock for the biogas plant. Therefore, the general objective of this study is to design an affordable co-digestion biogas plant for use at Phalombe Secondary School in Malawi.

\section{Materials and Methods}

This study was carried out at Phalombe Secondary school. The school is $1 \mathrm{~km}$ away from the central district of Phalombe and is situated $0.5 \mathrm{~km}$ away from Michesi Hill Forest which is the other source of firewood for the school's kitchen activities. The researcher engaged the school head and its members of staff to come up with the total energy demand (TED) at the school. The researcher also engaged village heads to establish the availability of livestock that would provide daily feeding material (substrate) for the biodigester at the school to supplement the already available daily feeding material at the school. The village heads engaged were Mbodi, Bokosi, and Seven. Also interviewed were owners of rice mills around Phalombe Secondary School who could provide rice husks/bran for free to be used for co-digestion.

\subsection{Data Collection Methods}

The data collection has been done through various methods including literature reviews concerning biogas plant designs and biogas production using different biodegradable wastes either as a single substrate or co-digested with other wastes, 
questionnaires, interviews, and observation. Primary data was collected through a baseline survey that included a questionnaire and personal observations in and around Phalombe secondary school where the study was carried out.

Secondary data was collected through literature reviews that included books, journals/articles, and websites. Data gathered from the literature review was used to determine the type of biogas plantto be used at Phalombe Secondary School. The Floating drum, Fixed dome, and the Polythene tube biodigester are three main digesters used worldwide. Each type of the three biogas plants mentioned above was thoroughly evaluated and the best design suitable for use at Phalombe Secondary school was selected using the Ranking method. Data for daily feeding material (DFM) was collected from both surrounding households and the administrator of the school. Also collected were data on the number of times of cooking per day at the school, number of staff and students at the school, disposal of kitchen waste, and annual temperatures of Phalombe district. All this data was required to come up with an appropriate design of a biogas plant that could supply Phalombe Secondary School with the right amount of gas for cooking and lighting. Other design considerations were based on the hydraulic retention time (HRT) and total solids (TS) content in the manures. From the literature review, the TS value desired is $8 \%$ and HRT is greater than 20 days. From this information, a TS value of $8 \%$ and HRT of 40 days was used in the design calculations for the biogas plant to be constructed at Phalombe Secondary School.

\subsection{Energy Demand Assessment}

The energy demand assessment has been done through a questionnaire, interviews, and site visit, therefore, data for energy demand (ED) for cooking and lighting was also collected. This helped to know how much electrical energy (EE) per day was being used by the school for lighting in the school classrooms, staff houses, kitchen, laboratories, and hostels. Also collected were data on the amount of firewood the school was using per school term. The electrical energy demand (EED) and the ED for firewood were then summed up and converted into biogas equivalence. It was from this sum of ED that the calculations for the size of the biogas plant were based. The respondents of the questionnaire on EED at the school for lighting were the head teacher of the school and other members of staff on duty during evening study times at the school. On the demand for firewood, the respondent of the questionnaire was the head cook. The respondents for ED for lighting at staff houses of the school were the head teacher and his fellow members of staff who are housed in the school compound.

The EED requirement was based on EE used by the staff members for lighting in their houses, EE used in the classrooms and offices for lighting during study times, EE used in the laboratories, student hostels, student kitchen, dining hall/canteen, and storeroom where kitchen facilities are kept. The EED in kilowatt-hour (kWhr) was summed up and converted to ED in Joules per day. This was then being converted to biogas flow rate per day $\left(\mathrm{m}^{3}\right.$ per day) as biogas equivalent from ED. Wood energy demand was calculated based on the amount 
of firewood the school is using in an academic term or year. This was then converted to the amount of firewood the school uses per day. Using the firewood to biogas-equivalent conversion, it came up with the amount of biogas in cubic meter $\left(\mathrm{m}^{3}\right)$ required per day $\left(\mathrm{m}^{3}\right.$ per day) for cooking in the kitchen as an alternative source of energy. The total amount of biogas required per day at the school for cooking and lighting was calculated by summing up the biogas equivalence for electrical lighting and firewood to biogas equivalent in $\mathrm{m}^{3}$ per day. Using the sum of biogas equivalence per day required at the school for cooking and lighting, the amount of HW required per day to be fed into the digester was determined. Based on the total amount of substrate to be fed into the biodigester (HW and CFW) and an estimated HRT of 40 days, the sizing of the biodigester, Gasometer, and the Digestate Collecting Tank was carried out. Detailed calculations are shown in the next section (section 2.5.3).

\subsection{Selection of the Type of Biogas Plant}

The tool used for this method was literature reviews on the common types of biogas plants in use globally for biogas production namely the Floating drum, Fixed dome, and the Polythene tube biodigester. The information of these types of biogas plants was gathered in terms of construction methods, availability of materials used in construction, the durability of materials, gas pressure holding ability, gas leakage through walls, gas pressure capacity, their life span, gas holding capacity, maintenance costs, their versatility in terms of construction(in high or low weather conditions), methane emission from each type, and other factors that should be considered when designing a biogas plant were sourced through this literature search. Each type of the three biogas plants mentioned above was thoroughly evaluated and the best design suitable for use at Phalombe Secondary school was selected. Based on literature detailed information about each of the three types of biogas plants, the fixed dome was selected [12] [14]. Although high skilled labor is required in the construction of a fixed dome biodigester, it has several advantages over the other types of biodigesters in AD [15]. Therefore, it was the preferred choice in the design selection. It consists of a digester with a fixed, non-movable gas holder that sits on top of the digester. When gas production starts, the slurry is displaced into the overflow tank. Gas pressure increases with the volume of the gas stored and the height of the difference between the slurry level in the digester and the slurry level in the compensation tank. There are no rusting steel parts in its construction hence long life (20 years or more). The plant is constructed underground, protecting it from physical damage and saving space. The underground digester is protected from low temperatures at night and cold seasons [12] [16].

\subsection{Statistical Analyses of Results}

A Biogas software called Online Biogas App (OBA) was used to simulate biogas production from the amount of substrate that was calculated/estimated in the 
design. The biogas yield was calculated from stoichiometry calculation, based on substrate compositions using OBA. Graphical presentations were drawn from the averaged results. All statistical work was done in Microsoft Excel 2016 (Microsoft Corporation, USA) and Past statistical software (version 4.03).

\subsection{System Analysis and Design}

\subsubsection{Design of the Biogas Plant}

Calculations for the sizing of the Biodigester tank, Gasometer, Digestate collection tank, and mixing tank were performed based on ED and available substrate at the school. These calculations were based on the fixed dome biogas plant which was selected as the best design suitable for use at Phalombe Secondary School. The information used in the design was taken from the following literature [12] [16]-[21].

\subsubsection{Designing the Size of a Biogas Plant}

All biogas plants have two useful parts that help to design the size of biogas plants. These parts are the digester which is the tank body and the gasometer which is commonly known as the dome. So for design calculations, these two main parts are considered. Other parts that have to be calculated are the sizing of the mixing tank and the digestate tank. The volume/size/capacity of a biogas plant depends on the HRT and the DFM. The DFM consists of organic biodegradable materials and water to be mixed with it. In this research, DFM includes HW, cow dung, FCW, and wastewater. Rice bran/straw was used for improving the C/N ratio of HW [8] [11]. Phalombe secondary school has an enrolment of 562 students and 195 members of the staff including their dependents. According to literature research, one adult human produces an average of $0.5 \mathrm{~kg}$ of $\mathrm{HW}$ [22]. For a simple biogas digester, the HRT is at least 40 days. But practical experience has shown that HRT can reach as far as 60 to 100 days if there is a shortage of daily feeding material. However, long HRT can increase the amount of gas produced by the biodigester by $40 \%$ of the initial production [23]. Since this study's main objective was to come up with a big plant required to produce a large quantity of biogas to satisfy the needs of the school, and HRT was to be estimated at 40 days (minimum).

\subsubsection{Design Calculations}

\section{1) Energy demand calculations}

To come up with the correct size of the biogas plant that can serve the two purposes of cooking and lighting at the school, detailed calculations were carried out to determine the ED at the school as follows:

a) Classroom demand (for studies)

Number of classrooms $=8$.

Number of 22 watts $(\mathrm{W})$ fluorescent bulbs per classroom $=2$.

Lighting time (from $6 \mathrm{pm}$ to $10 \mathrm{pm})=4$ hours $(\mathrm{h})$.

Therefore, energy $(E)$ required in kilowatt-hour (kWh) during study time 


$$
E=8 \times 2 \times 4 \times 22 / 1000=1.4 \mathrm{kWh}
$$

b) Laboratories

Biology, Physics, and Chemistry labs $2 \times 22 \mathrm{~W}$ fluorescent tubes each.

Lighting time (from $6 \mathrm{pm}$ to $10 \mathrm{pm}$ ) $=4 \mathrm{~h}$

$$
E=3 \times 2 \times(22 \mathrm{~W}) / 1000=0.4 \mathrm{kWh}
$$

c) Student hostels

Number of hostels $=12$.

Number of rooms per hostel $=10$.

Each room uses $1 \times 22 \mathrm{~W}$ fluorescent tube for 5 hours lighting $(6-10 \mathrm{pm}$, 03:00-04:00 am). Therefore, the energy required in the student hostels, $E$ is given by Equation (3)

$$
E=12 \times 10 \times 5 \times(22 \mathrm{~W}) / 1000=13.2 \mathrm{kWh}
$$

Each hostel uses a $2 \times 22 \mathrm{~W}$ security light (one inside and one outside).

Therefore, the energy required for security lighting at the hostels is given by Equation (4)

$$
\begin{gathered}
E=2 \times 12 \times 10 \times(22 \mathrm{~W}) / 1000=5.3 \mathrm{kWh} \text { per day } \\
\text { Subtotal }=(13.2+5.3) \mathrm{kWhr}=18.5 \mathrm{kWhr}
\end{gathered}
$$

d) Staff houses

40 houses, 3 bulbs per house, $10 \mathrm{~W}$ with an average lighting period of 6 hours, $E$ is given by Equation (6)

$$
E=40 \times 3 \times 6 \times(10 \mathrm{~W}) / 1000=7.2 \mathrm{kWh} \text { per day }
$$

One security light of $22 \mathrm{~W}$ per house with a lighting period of 10 hours, $E$ is given by Equation (7)

$$
\begin{gathered}
E=1 \times 40 \times 10 \times(22 \mathrm{~W}) / 1000=0.8 \mathrm{kWh} \text { per day } \\
\text { Subtotal }=(7.2+0.8) \mathrm{kWhr}=8.0 \mathrm{kWhr}
\end{gathered}
$$

e) Students Kitchen

Energy required for $3 \times 22 \mathrm{~W}$ fluorescent tubes for 6 hours lighting and $2 \times 22$ W fluorescent tubes security lights for 10 hours is calculated using Equation (9) and (10)

$$
\begin{gathered}
E=3 \times 6 \times(22 \mathrm{~W}) / 1000=0.4 \mathrm{kWh} \text { per day } \\
E=2 \times 10 \times(22 \mathrm{~W}) / 1000=0.4 \mathrm{kWhr} \text { per day } \\
\text { Subtotal }=(0.4+0.4) \mathrm{kWhr} \text { per day }=0.8 \mathrm{kWhr}
\end{gathered}
$$

f) Dining Hall

The energy required for $8 \times 22 \mathrm{~W}$ fluorescent tubes for 2 hours is calculated as follow (12)

$$
E=8 \times 2 \times(22 \mathrm{~W}) / 1000=0.4 \mathrm{kWh} \text { per day }
$$


g) Storeroom

The energy required for a $1 \times 22 \mathrm{~W}$ fluorescent tube for 6 hours is given by Equation (13)

$$
E=1 \times 6 \times(22 \mathrm{~W}) / 1000=0.1 \mathrm{kWh} \text { per day }
$$

The total lighting energy required per day is summarized in Table 1.

2) Energy conversion

$$
1 \mathrm{kWh}=3.6 \times 10^{6} \text { Joules }
$$

Therefore,

$$
E=30 \mathrm{kWh}=3.6 \times 10^{6} \text { joules } \times 30 \mathrm{kWh} / 1 \mathrm{kWh}=108 \mathrm{MJ} \text { per day }
$$

According to [14], a mixture of human and kitchen waste produce $0.15 \mathrm{~m}^{3}$ per $\mathrm{kg}$ of biogas.

Assuming that this is possible with an HRT of 40 days as per the researcher's design and using the calorific value of biogas is $20 \mathrm{MJ}$ per $\mathrm{m}^{3}$ (MJ: megajoule), then the daily biogas flow rate can be calculated as follows:

Daily Biogas flow rate

$=$ daily energy requirement $\div$ calorific value of fuel

$$
=108 \mathrm{MJ} \div 20 \mathrm{MJ}=5.40 \mathrm{~m}^{3} \text { per day }
$$

\section{3) Firewood to biogas equivalent}

Phalombe Secondary School uses 52 tons of firewood in a school calendar. The school runs on three terms of 12 weeks each on average. 12 weeks is equal to 84 days.

Therefore, the number of tons of firewood required per day is given by Equation (17)

$$
\begin{aligned}
& 52 \times 1 /(3 \times 84)=0.206 \text { ton per day } \\
& \text { but } 1 \text { ton }=1000 \text { kilogram }(\mathrm{kg})
\end{aligned}
$$

Therefore, 0.206 ton per day $=1000 \times 0.206 \mathrm{~kg}$ per day $=206 \mathrm{~kg}$ per day.

Table 1. Summary of energy demand at phalombe boarding secondary school.

\begin{tabular}{cc}
\hline Section of School & ED (kWhr per day) \\
Classrooms & 1.4 \\
Laboratories & 0.4 \\
Student hostels & 18.5 \\
Staff houses & 8.0 \\
Students kitchen & 0.8 \\
Dining hall & 0.4 \\
Storeroom & 0.1 \\
Total & $29.6 \approx 30$ \\
\hline
\end{tabular}


According to Biogas Digest Volume III, Biogas applications and product development, biogas costs and benefits, ISAT, GTZ [24].

$$
\begin{aligned}
& 1 \mathrm{~m}^{3} \text { biogas }=5.5 \mathrm{~kg} \text { of firewood } \\
& \text { So if } 5.5 \mathrm{~kg}=1 \mathrm{~m}^{3} \text { of biogas }
\end{aligned}
$$

Therefore, $206 \mathrm{~kg}$ of firewood $=1 \times 2065.5 \mathrm{~m}^{3}$ of biogas $=37.45 \mathrm{~m}^{3}$ per day.

Therefore, the total amount of biogas $(Y)$ required at Phalombe Secondary School for lighting and cooking is calculated using Equation (21)

$$
Y=\left(5.40 \mathrm{~m}^{3}+37.45 \mathrm{~m}^{3}\right) \text { per day }=42.85 \mathrm{~m}^{3} \text { per day }
$$

The quantity of $\mathrm{HW}\left(Q_{\mathrm{HW}}\right)$ required is given by the amount of gas produced per day over gas production per kg from $\mathrm{HW}$ [25].

$$
Q_{\mathrm{HW}}=42.85 / 0.15 \mathrm{~kg}=286 \mathrm{~kg} \text { per day }
$$

With the number of people at Phalombe secondary being 757 and on average a human being produces $0.5 \mathrm{~kg}$ of $\mathrm{HW}$, we expect the amount of $\mathrm{HW}$ produced in a day to be

$$
0.5 \times 757 \mathrm{~kg}=378.5 \mathrm{~kg} \text { per day }
$$

This amount of HW exceeds the requirement per day. Therefore, Phalombe Secondary School has enough HW to supply the digester to be constructed at the school.

From this organic material (ORM) will be added CFW of $60 \mathrm{~kg}$ per day, therefore,

$$
\mathrm{ORM}=(286+60) \mathrm{kg} \text { per day }=346 \mathrm{~kg} \text { per day }
$$

Add 1:1 ratio of ORM to Water becomes

$$
346 \mathrm{~kg} \text { per day } \times 2=692 \mathrm{~kg} \text { per day substrate }
$$

And according to [18], TS $=16 \%$ of the mass of substrate

$$
=16 \% \times 692 \mathrm{~kg} \text { per day }=110.72 \mathrm{~kg} \text { per day }
$$

Quantity $(Q)$ of the substrate is given by Equation (27)

$$
Q=\mathrm{TS} / 8 \%
$$

Therefore, the required $Q=110.72 / 0.08 \mathrm{~kg}$ per day $=1384 \mathrm{~kg}$ per day.

\subsubsection{Sizing of the Digester, Gasometer, Digestate Collection Tank, and Mixing Tank \\ 1) Sizing of the Digester}

Given $Q=1384 \mathrm{~kg}$ per day, HRT $=40$ days and density of slurry $=1000 \mathrm{~kg}$ per $\mathrm{m}^{3}$.

The operating volume of the digester $\left(V_{0}\right)$ is calculated using Equation (28),

$$
V_{0}=Q \times \text { HRT } / 1000 \mathrm{~m}^{3}=1384 \times 40 / 1000 \mathrm{~m}^{3}=55.36 \mathrm{~m}^{3}
$$

But $V_{0}=90 \%$ of $V_{T}$ where $V_{T}$ is the total volume of the digester [25].

Therefore $V_{T}=V_{0} / 90 \%=55.36 / 0.9 \mathrm{~m}^{3}=61.51 \mathrm{~m}^{3}$ 
According to [18], the height of a digester is 4 times its radius $(r)$ i.e. $h=4 r$, but

$$
\begin{gathered}
V_{T}=\pi r^{2} h=\pi r^{2} \times 4 r=4 \pi r^{3} \\
V_{T} \div 4 \pi=r^{3} \\
r=\sqrt[3]{61.51 / 4 \pi}=1.698 \mathrm{~m}=1.7 \mathrm{~m}
\end{gathered}
$$

Diameter of the digester becomes $2 r=2 \times 1.7 \mathrm{~m}=3.4 \mathrm{~m}$

Height of the digester becomes $4 r=4 \times 1.7 \mathrm{~m}=6.8 \mathrm{~m}$

\section{2) Sizing the Gasometer}

According to [15] the volume of biogas from cow dung per $\mathrm{kg}=0.000616 \mathrm{~m}^{3}$. According to [26] biogas yields ( $\mathrm{m}^{3}$ per kg daily solids) for cow manure and $\mathrm{HW}$ are 0.3 and 0.4 respectively. The difference between the two yields is very small. The yield from HW will be improved by the addition of CFW as per the researcher's design of the biogas plant. For this reason, a value of $0.000616 \mathrm{~m}^{3}$ is used to calculate the volume $V_{g}$ of the gasometer as follows:

$$
V_{g}=\text { Volume of biogas per day } \times \mathrm{DFM} \times \mathrm{HRT}
$$

where Volume of biogas per day $=0.000616 \mathrm{~m}^{3}, \mathrm{DFM}=692 \mathrm{~kg}$ per day and HRT $=40$ days, then

$$
V_{g}=0.000616 \mathrm{~m}^{3} \text { per } \mathrm{kg} \times 692 \mathrm{~kg} \text { per day } \times 40 \text { days }=17.05 \mathrm{~m}^{3}
$$

An allowance of $10 \%$ is given.

Therefore,

$$
V_{g}=V_{g}+\left(0.1 \times V_{g}\right)=17.05+(0.1 \times 17.05) \mathrm{m}^{3}=18.76 \mathrm{~m}^{3}
$$

In practice, the ratio $V_{g}: V_{0}$ where $V_{0}$ is the operating volume of the digester, which is commonly used is between 1:3 and 1:5 [18] [27] [28]. According to this design, the ratio is $18.76: 55.36=1: 3$, so the design is feasible.

Taking the height, the gasometer to be 4 times its radius, the diameter, and height of the gasometer can be calculated as follows:

$$
\begin{gathered}
V_{g}=\pi r^{2} h \text { where } h=4 r \\
V_{g}=\pi r^{2} \times 4 r=4 \pi r^{3} \\
r=\sqrt[3]{V_{g} / 4 \pi}=\sqrt[3]{18.75 / 4 \pi}=1.14 \mathrm{~m} \\
D=1.14 \mathrm{~m} \times 2=2.28 \mathrm{~m} \\
H=1.14 \mathrm{~m} \times 4=4.56 \mathrm{~m}
\end{gathered}
$$

\section{3) Sizing the Digestate collection Tank (Overflow tank)}

The Digestate tank can take the shape of a rectangle, square, or circle. For the digestate collection tank, a $10 \%$ allowance is given for mixing.

a) Circular tank sizing

The volume of collection tank $\left(V_{c}\right)$,

$$
V_{c}=V_{0}+\left(0.1 \times V_{0}\right)=55.36+(0.1 \times 55.36)=60.89 \mathrm{~m}^{3}
$$


The height of the tank is 1.5 times its radius [18], but

$$
V_{c}=\pi r^{2} h
$$

Therefore,

$$
\begin{gathered}
V_{c}=\pi r^{2} \times 1.5 r \\
V_{c}=\pi r^{3} \times 1.5 \\
60.89=1.5 \pi r^{3} \\
r^{3}=40.597 \mathrm{~m} \\
r=3.44 \mathrm{~m} \\
D=6.88 \mathrm{~m} \\
h=1.5 r=1.5 \times 3.44 \mathrm{~m} \\
h=5.16 \mathrm{~m} \approx 5.0
\end{gathered}
$$

b) For a square base tank, the volume ( $V$ ) will remain the same i.e. $60.89 \mathrm{~m}^{3}$ and height of $5.0 \mathrm{~m}$

$$
V=L^{2} \times H
$$

Therefore,

$$
\begin{gathered}
60.89 \mathrm{~m}^{3}=5.0 L^{2} \\
L^{2}=60.89 / 5.0=12.178 \mathrm{~m}^{2} \\
L=\sqrt{12.178} \mathrm{~m}^{2}=3.5 \mathrm{~m}
\end{gathered}
$$

\section{4) Sizing mixing tank for kitchen wastes/agriculture waste/cow dung}

Since the tank will be accommodating $60 \mathrm{~kg}$ of kitchen wastes per time, the following dimensions have been suggested to be reasonable:

Depth of mixing tank $=1.0 \mathrm{~m}$

The diameter of mixing tank $=0.9 \mathrm{~m}$

The volume of the mixing tank $=\pi r^{2} h=\pi \times(0.3 \mathrm{~m})^{2} \times 1.0 \mathrm{~m}=0.28 \mathrm{~m}^{3}$

Table 2 shows a summary of the sizing of the designed Fixed Dome Biogas plant.

\subsubsection{Development of a Detailed Biogas Plant Drawing}

Detailed drawings were produced to be used by the masonry builders when constructing the biogas plant. A computer-aided design (Auto CAD) software was used for the drawing biogas plant layout out Phalombe Boarding Secondary School as shown in Figure 1 while Figure 2 was sourced from Rwandan Standards Board. This is the standard fixed dome biogas plant that is used worldwide. The major dimensions in Table 3 are from the calculations in the sizing of the Digester tank, Gasometer, Digestate tank, and the Mixing tank.

The detail drawing in Figure 2 will be used by the masonry builders to construct a biogas plant at Phalombe Secondary School. The Mixing and Biodigester (digester) tanks are cylindrical while the Digestate tank is square. 


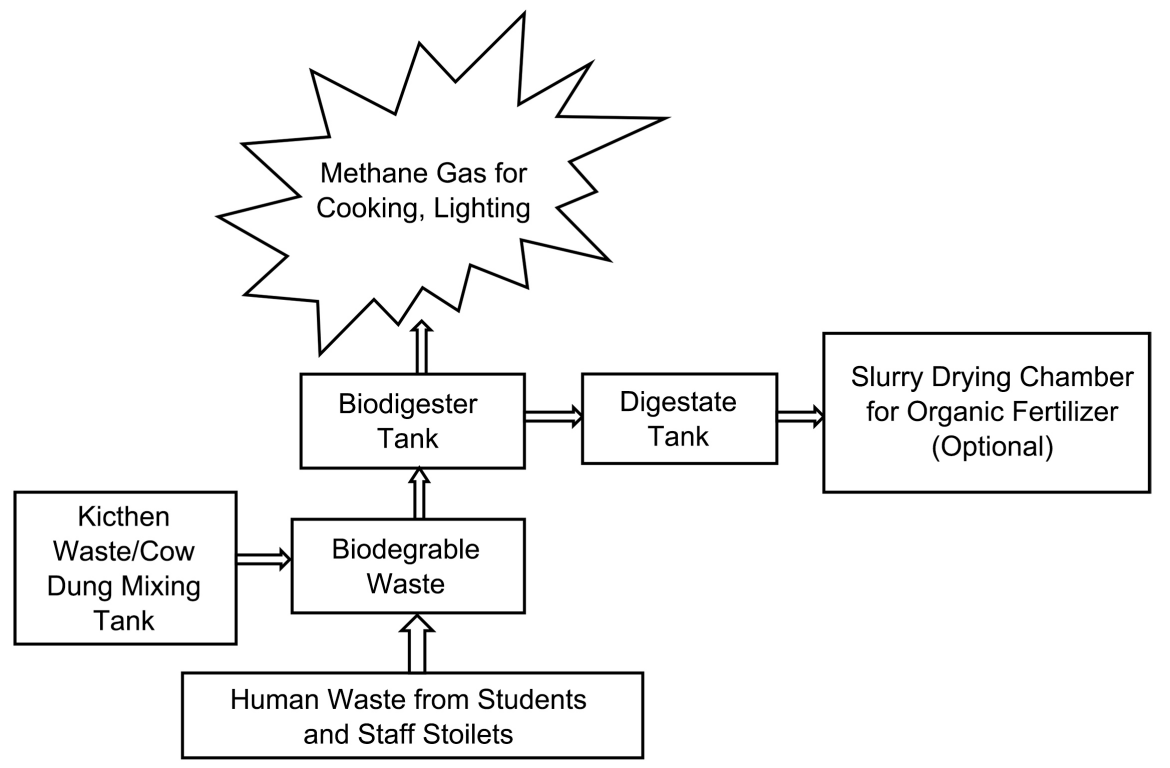

Figure 1. Biogas plant layout.

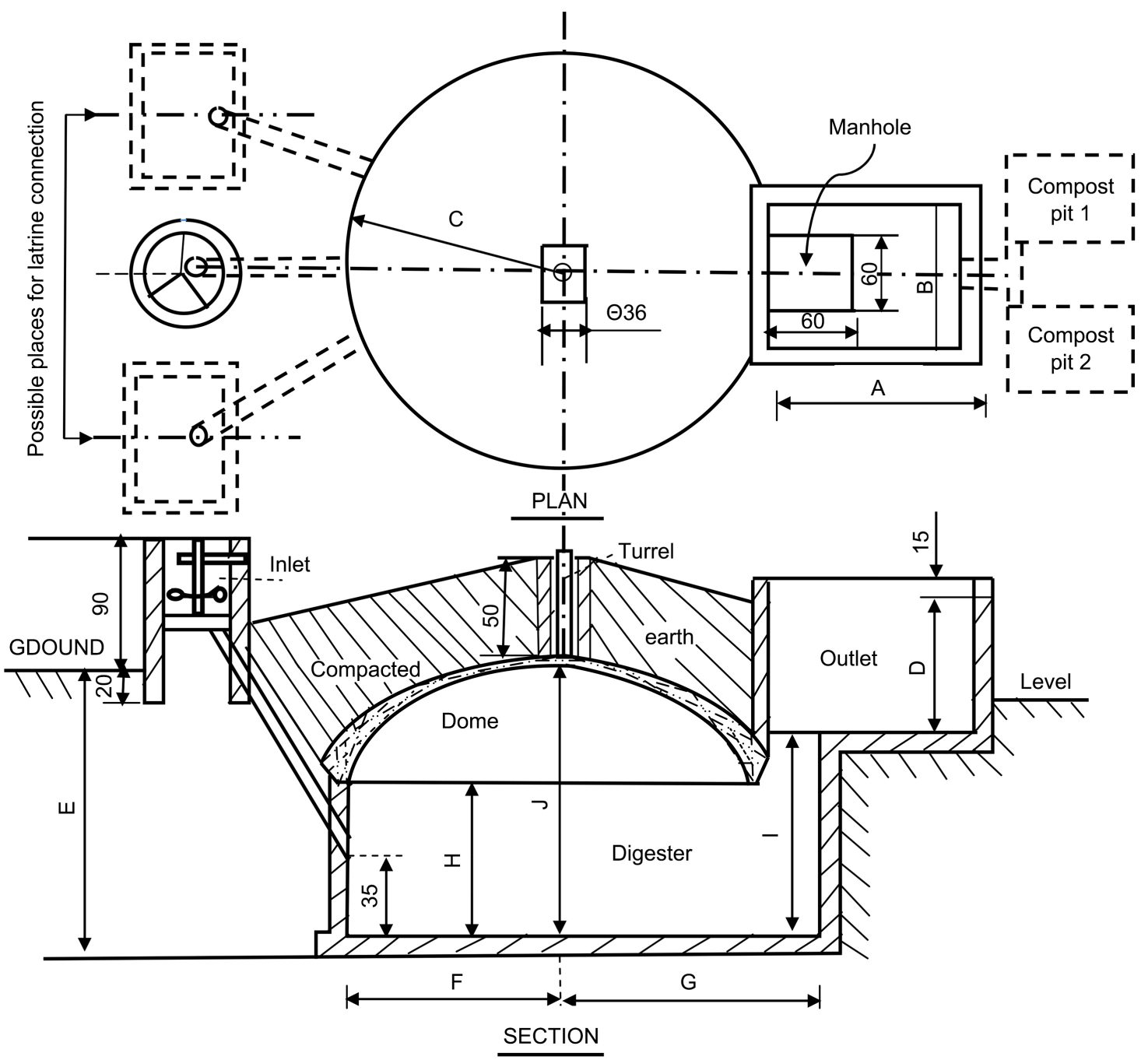

Figure 2. Detail drawing of fixed dome biogas plant. Source: [16] [27] [28]. 
Table 2. Summary of sizing of the fixed dome biogas plant.

\begin{tabular}{cccccccc}
\hline Parameter & $\begin{array}{c}\text { Volume } \\
\left(\mathrm{m}^{3}\right)\end{array}$ & $\begin{array}{c}\text { Height } \\
(\mathrm{m})\end{array}$ & $\begin{array}{c}\text { Radius } \\
(\mathrm{m})\end{array}$ & $\begin{array}{c}\text { Diameter } \\
(\mathrm{m})\end{array}$ & $\begin{array}{c}\text { Thickness } \\
(\mathrm{m})\end{array}$ & $\begin{array}{c}\text { Length } \\
(\mathrm{m})\end{array}$ & $\begin{array}{c}\text { Width } \\
(\mathrm{m})\end{array}$ \\
\hline Biodigester & 61.51 & 6.80 & 1.70 & 3.40 & 0.32 & - & - \\
Gasometer & 18.76 & 4.56 & 1.14 & 2.28 & 0.32 & - & - \\
Mixing tank (CFW) & 0.57 & 0.90 & 0.45 & 0.90 & 0.15 & - & - \\
Digestate Tank & 60.89 & 5.00 & 3.44 & 6.88 & 0.0 .32 & 3.50 & 3.50 \\
\hline
\end{tabular}

Table 3. Major dimensions of the fixed dome biogas plant.

\begin{tabular}{cccccc}
\hline Component & Dimension (m) & Component & Dimension & Component & Dimension \\
\hline A & 3.50 & E & 6.80 & J & 6.80 \\
B & 3.50 & F & 1.70 & \\
C & 1.70 & G & 2.62 & \\
D & 5.00 & H & 5.66 & \\
E & & I & 5.86 & \\
\hline
\end{tabular}

\subsubsection{Design Cost Estimates}

The size of the designed biogas plant was used to estimate the cost of building this biogas plant at the school. The costs of using firewood for cooking and electricity for lighting at the school were compared with that of building the designed biogas plant. Bills of quantities for the sized biogas plant were used to come up with the cost of constructing the biogas plant at the school. The bill of quantities for the $62 \mathrm{~m}^{3}$ biogas digester is shown in Table 4. Exchange rate: $M K 800=$ US\$1.

\subsubsection{Simulation of Biogas Production Using Quantities of the Substrate in the Design}

A Biogas software called Online Biogas App (OBA) was used to simulate biogas production from the amount of substrate that was calculated in the design. Three biogas production simulations were run (Figures 3-5) using:

1) HW only as a substrate

2) CFW only as a substrate and

3) Co-digestion of HW and CFW

The results for each simulation were then analyzed.

\section{1) Design Simulation}

This design simulation was based on the type of biomass, amount of biomass, the molecular composition of the biomass, $\mathrm{PH}$ in the biodigester, and the temperature required for methane gas production. This Biogas Simulation software was written and developed by [29] with assistance from Jon Katz. 
Table 4. Bill of quantities for a $62 \mathrm{~m}^{3}$ biodigester.

\begin{tabular}{|c|c|c|c|c|c|}
\hline Item & Description & Qty & Unit & Unit Price (\$) & Amount (\$) \\
\hline \multirow[t]{23}{*}{1} & \multicolumn{5}{|c|}{ Accessories } \\
\hline & Black enamel paint & 15 & Liter & 20.0 & 300.00 \\
\hline & 110 mm PVC Pipe & 20 & length & 8.75 & 175.00 \\
\hline & Watering can & 3 & NA & 5.0 & 15.00 \\
\hline & Flexible hose & 600 & $\mathrm{~m}$ & 0.38 & 228.00 \\
\hline & Wheelbarrow heavy duty & 2 & NA & 50.00 & 100.00 \\
\hline & Thread tapes & 12 & NA & 0.044 & 0.53 \\
\hline & Shovels (excavation work) & 4 & NA & 10.00 & 40.00 \\
\hline & Hoes/handles (excavation work) & 6 & NA & 4.38 & 26.28 \\
\hline & Pails & 3 & NA & 6.25 & 18.75 \\
\hline & Black plastic sheet & 2 & NA & 4.38 & 8.76 \\
\hline & Butterfly valves & 6 & NA & 6.88 & 41.28 \\
\hline & G.I. Union & 10 & NA & 0.63 & 6.30 \\
\hline & G.I. Elbow & 10 & NA & 0.63 & 6.30 \\
\hline & G.I. Tee joint & 10 & NA & 0.63 & 6.30 \\
\hline & G.I. Socket & 12 & NA & 0.63 & 7.56 \\
\hline & G.I. Nipple & 12 & NA & 0.63 & 7.56 \\
\hline & G.I. Pipes & 14 & length & 8.75 & 122.5 \\
\hline & G.I. R. Bush & 20 & NA & 0.63 & 12.60 \\
\hline & Lime & 10 & $\mathrm{~kg}$ & 0.75 & 7.50 \\
\hline & Paintbrush & 4 & NA & 4.38 & 17.52 \\
\hline & Wire brush & 2 & NA & 4.38 & 8.76 \\
\hline & Subtotal & & & & 1156.50 \\
\hline \multirow[t]{12}{*}{2} & \multicolumn{5}{|c|}{ Building Materials } \\
\hline & Bricks & 20,000 & NA & 0.025 & 500.00 \\
\hline & Transport & NA & NA & 50.00 & 50.00 \\
\hline & Cement (50kg) & 60 & Bags & 10.00 & 600.00 \\
\hline & Transport & NA & NA & 50.00 & 50.00 \\
\hline & Quarry stones & 12 & Tons & 10.63 & 127.56 \\
\hline & Transport & NA & NA & 10.00 & 10.00 \\
\hline & Fine Sand & 4 & Tons & 2.50 & 10.00 \\
\hline & Transport & NA & NA & 18.75 & 18.75 \\
\hline & Course sand & 10 & Tons & 6.25 & 62.50 \\
\hline & Transportui & NA & NA & 10.00 & 10.00 \\
\hline & Subtotal & & & & 1388.81 \\
\hline
\end{tabular}


Continued

\begin{tabular}{|c|c|c|c|c|c|}
\hline \multirow[t]{6}{*}{3} & \multicolumn{5}{|c|}{ Other Costs } \\
\hline & Shuttering materials & 60 pcs of timber & NA & 1.25 & 75.00 \\
\hline & Transport & & & & 37.50 \\
\hline & Outlet covers (student and staff kitchens) & 2 & NA & 4.38 & 8.76 \\
\hline & Training of biogas users & 2 & days & NA & 125.00 \\
\hline & Subtotal & & & & 246.26 \\
\hline \multirow[t]{5}{*}{4} & \multicolumn{5}{|c|}{ Labour } \\
\hline & Mason (skilled) & 2 & NA & 5.00 per day for 30 days & 300.00 \\
\hline & Casual labour (water/construction) & 6 & NA & 37.5 & 225.00 \\
\hline & Plumber & 2 & NA & 5.00 per day for 10 days & 100.00 \\
\hline & Subtotal & & & & 625.00 \\
\hline \multirow[t]{8}{*}{5} & \multicolumn{5}{|c|}{ Administration } \\
\hline & Board \& Lodgings & 1 & NA & 25.00 per day for 30 days & 750.00 \\
\hline & Communication & 1 & NA & 1.45 per day for 30 days & 43.50 \\
\hline & Consultation, reporting, supervision fee & 1 & NA & 21.00 per day for 30 days & 630.00 \\
\hline & Transport/fuel & 1 & NA & 12.50 per day for 30 days & 375.00 \\
\hline & Survey & 1 & NA & 31.25 per day for 2 days & 62.50 \\
\hline & Subtotal & & & & 1861.00 \\
\hline & Grand Total & & & & 5277.57 \\
\hline
\end{tabular}

NA: not applicable, Qty: quantity, \$: USA dollar, MK: Malawian Kwacha, G.I: Galvanized Iron.

\section{2) Inputs and outputs for OBA simulation Software}

The inputs for this simulation process are as follows:

a) Substrate composition (\%)

b) Mass of the substrate $(\mathrm{kg})$

c) Substrate biodegradability (\%DM)

d) Substrate partitioning to cell synthesis (\%)

e) Reactor $\mathrm{pH}$ and

f) Reactor temperature $\left({ }^{\circ} \mathrm{C}\right)$

The outputs are as follows:
a) Methane production
b) Carbon dioxide production
c) Nitrogen production and other impurities
d) Total Biogas production

This biogas plant uses HW as well as CFW as biomass material for feeding the biodigester. The parameters for each type of biomass are tabulated in Table 5. 
Table 5. Parameters for simulation of biogas production.

\begin{tabular}{|c|c|c|c|c|}
\hline Biomass & $\begin{array}{l}\text { Quantity } \\
\text { in kg }\end{array}$ & $\begin{array}{c}\text { Macromolecular } \\
\text { composition (\%DM) }\end{array}$ & $\begin{array}{c}\text { The temperature in } \\
\text { the digester with } \\
\text { HRT of } 40 \text { days }\end{array}$ & $\begin{array}{l}\mathrm{pH} \text { in the } \\
\text { digester }\end{array}$ \\
\hline \multirow{3}{*}{ CFW } & \multirow{3}{*}{60} & Carbohydrate (45\%) & \multirow{3}{*}{$55^{\circ} \mathrm{C}$} & \multirow{3}{*}{7.5} \\
\hline & & Proteins (15\%) & & \\
\hline & & Lipids (40\%) & & \\
\hline \multirow{6}{*}{ HW } & \multirow{6}{*}{286} & Carbohydrates (11\%) & \multirow{10}{*}{$55^{\circ} \mathrm{C}$} & \multirow{6}{*}{7.5} \\
\hline & & Water (65\%) & & \\
\hline & & Ash (15\%) & & \\
\hline & & Fats $(15 \%)$ & & \\
\hline & & Nitrogen (3\%) & & \\
\hline & & Protein (3\%) & & \\
\hline \multirow{4}{*}{ Co-digestion } & \multirow{4}{*}{346} & Carbohydrate (56\%) & & \\
\hline & & Protein (18\%) & & \\
\hline & & Ash (15\%) & & \\
\hline & & Lipids (30\%) & & \\
\hline
\end{tabular}

\section{3) Results of simulation}

\section{a) Simulation of biogas production from $\mathrm{HW}$}

The amount of HW whose mass was $286 \mathrm{~kg}$ as the amount of organic material in the design was used as input into the digester. The macromolecular composition (\%DM) of the HW was $11 \%$ carbohydrate, $3 \%$ protein, $15 \%$ lipids, and $15 \%$ ash (Figure 3). Since HW are highly biodegradable, the substrate degradability was at $90 \%$. The digester $\mathrm{pH}$ was 7.5 with a mesophilic temperature of $55^{\circ} \mathrm{C}$. Figure 3 shows the results of theoretical gas production using HW.

\section{b) Simulation of biogas production from CFW}

The amount of CFW whose mass was $60 \mathrm{~kg}$ as the amount of organic material in the design was used as input into the digester. The macromolecular composition (\%DM) of the CFW was $45 \%$ carbohydrate, $15 \%$ protein. $40 \%$ lipids, and $0 \%$ ash (Figure 4). Since CFW are highly biodegradable, the substrate degradability was at $90 \%$. The reactor $\mathrm{pH}$ was 7.5 with a mesophilic temperature of $55^{\circ} \mathrm{C}$. Figure 4 shows the results of theoretical gas production using CFW.

c) Simulation of biogas production using co-digestion of HW and CFW

The amount of CFW whose mass was $60 \mathrm{~kg}$ was mixed with $286 \mathrm{~kg}$ of HW making a total co-digestion substrate of $346 \mathrm{~kg}$ as amount of organic material in the design was used as input into the digester. The macromolecular composition of the mixture was $56 \%$ carbohydrate, $18 \%$ protein, $30 \%$ lipids, and $15 \%$ ash. Since both HW and CFW are highly biodegradable, the substrate degradability was estimated at $90 \%$. The reactor $\mathrm{pH}$ was 7.5 with a mesophilic temperature of $55^{\circ} \mathrm{C}$. Figure 5 shows the results of theoretical gas production using co-digestion of $\mathrm{HW}$ and CFW. 


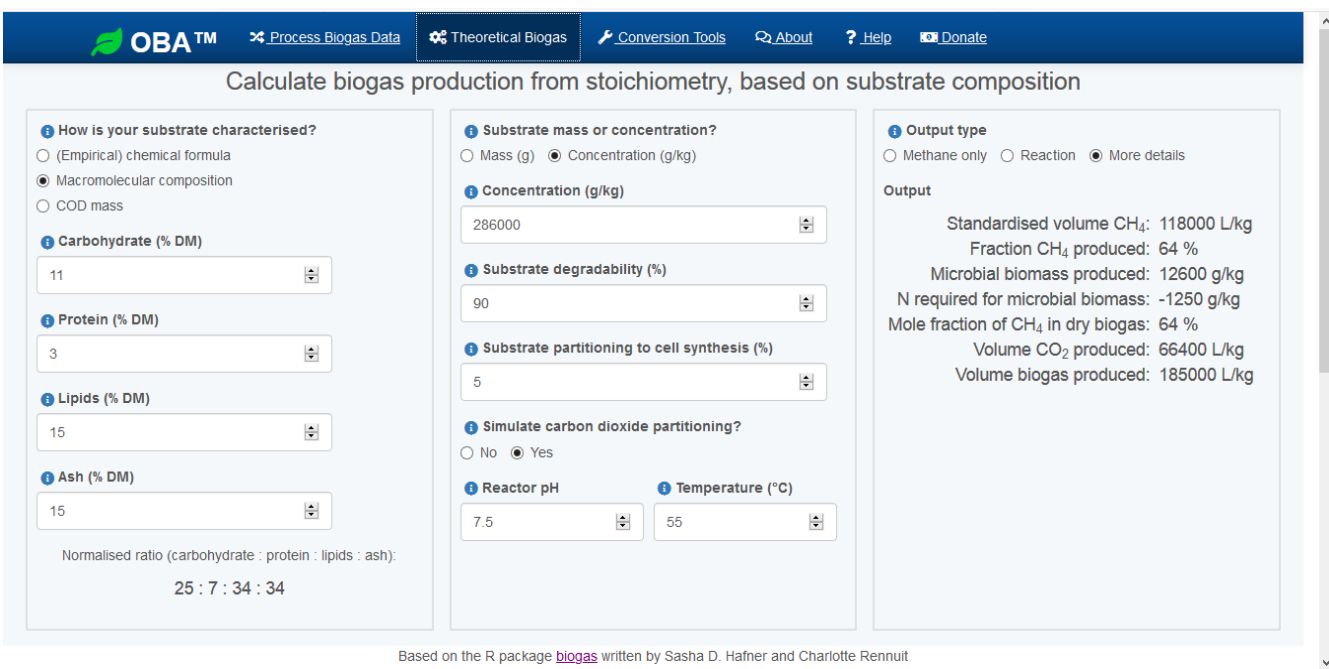

Figure 3. Theoretical biogas production from HW.

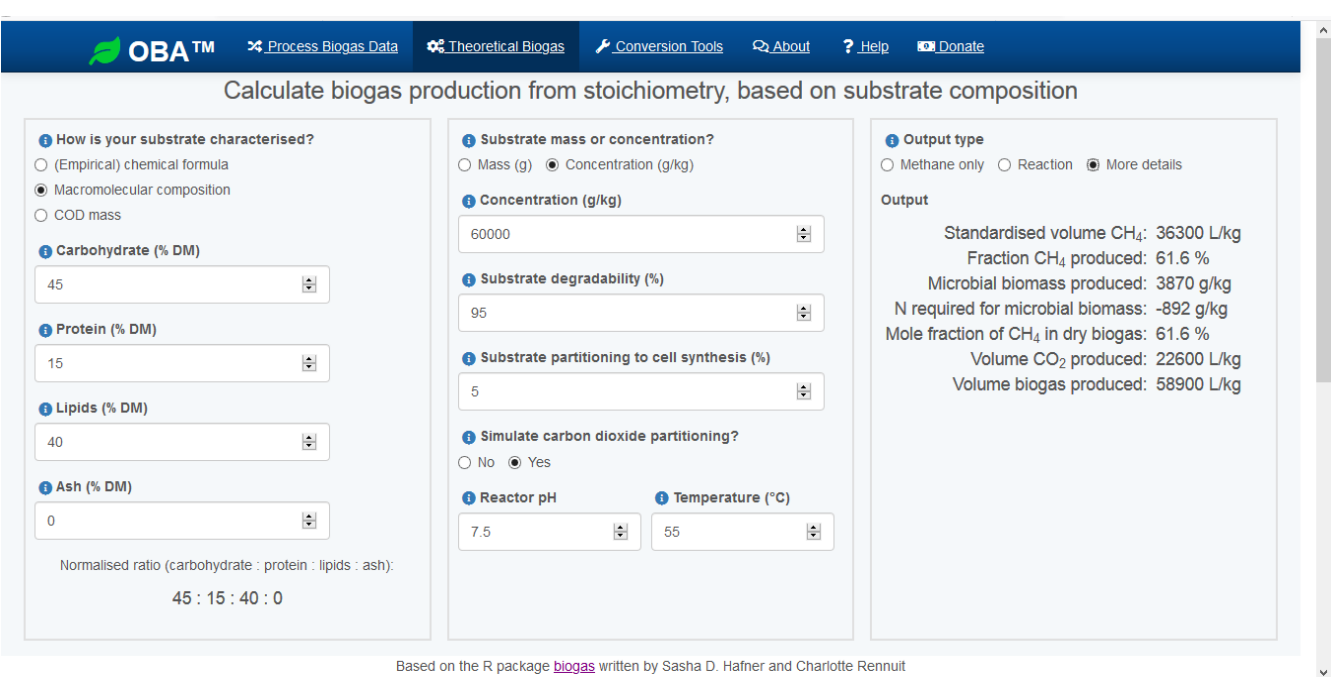

Figure 4. Theoretical biogas production from CFW.

\section{$\sigma$ OBA ${ }^{\text {TM }} \approx$ Process Biogas Data Theoretical Biogas conversion Tools ex About ? Help Donate}

Calculate biogas production from stoichiometry, based on substrate composition

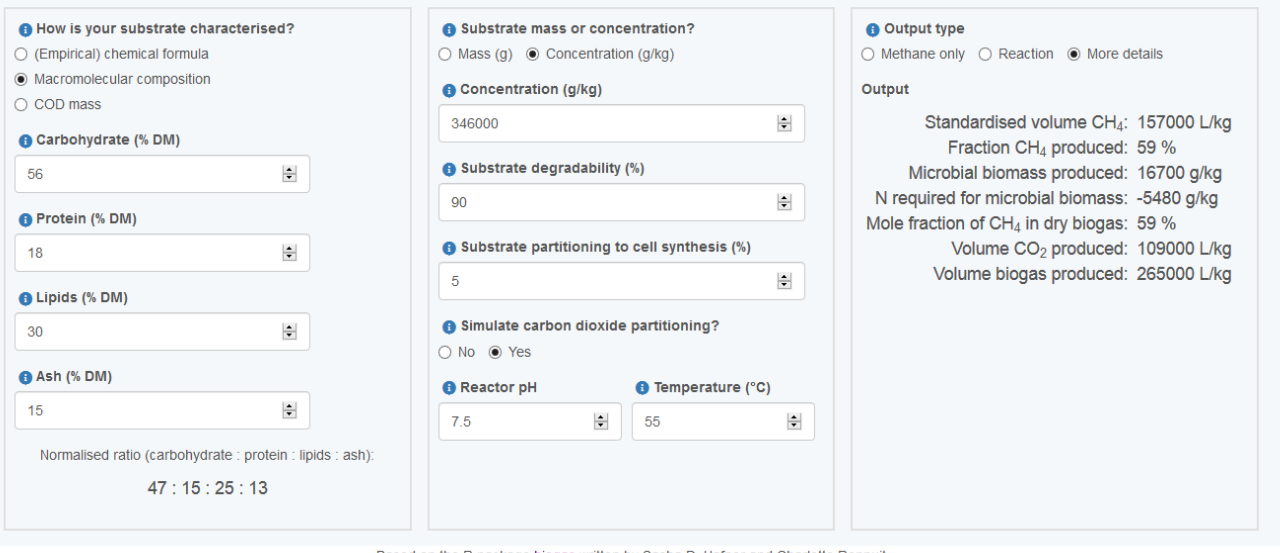

Based on the $\mathrm{R}$ package biogas written by Sasha $\mathrm{D}$. Hafner and Charlotte Rennuit

Figure 5. Theoretical biogas production from co-digestion of HW and CFW. 


\section{Results and Discussions}

This section presents the results of the design including simulation of biogas production, comparison of the results with existing literature, discussion of the feasibility of the design, cost comparison between the design, and the continued use of firewood as the source of energy for cooking at Phalombe Secondary School. Thestudy design was based on the use of HW and CFW as the substrate for the biodigester to produce methane gas that could be used for cooking and lighting at Phalombe Secondary School to replace firewood. With a school population of 757 people, design calculations/estimations were performed to find out the amount of HW required per day. The design came up with an amount of HW as $286 \mathrm{~kg}$ per day. An estimated $60 \mathrm{~kg}$ of CFW per day was used, making a total ORM of $346 \mathrm{~kg}$ per day. These wastes were co-digested for biogas production. Based on the ED at the school, a $61 \mathrm{~m}^{3}$ biogas plant that could co-digest these wastes was designed using theories from the literature [18] [19] [20] [21] [30] [31].

\subsection{Simulation of the Design}

Using HW and CFW separately as substrates and then using the mixture as substrate simulations were run (Figures 3-5). The results were as follows Simulation 1: Theoretical biogas production from HW, Simulation 2: Theoretical biogas production from CFW, and Simulation 3: Theoretical biogas production from co-digestion of HW and CFW as shown in Table 6, Table 7, and Table 8 respectively.

Table 6. Results of Simulation 1 from HW.

\begin{tabular}{|c|c|c|c|c|c|c|}
\hline Input & $\begin{array}{l}\text { Quantity } \\
\text { (kg) }\end{array}$ & $\begin{array}{l}\text { Macromolecular } \\
\text { composition } \\
(\% \mathrm{DM})\end{array}$ & $\begin{array}{c}\text { Substrate } \\
\text { degradability } \\
(\%)\end{array}$ & $\begin{array}{l}\text { The temperature } \\
\text { in the digester } \\
\text { with HRT of } \\
40 \text { days }\end{array}$ & $\begin{array}{l}\mathrm{pH} \text { in the } \\
\text { digester }\end{array}$ & Output \\
\hline HW & 286 & $\begin{array}{c}\text { Carbohydrates 11\% } \\
\text { Ash 15\% } \\
\text { Lipids 15\% } \\
\text { Protein 3\% }\end{array}$ & \% & $55^{\circ} \mathrm{C}$ & 7.5 & $\begin{array}{l}\text { The standardized volume of } \mathrm{CH}_{4} \text { was } 118,000 \mathrm{~L} \text { per } \mathrm{kg} 1\left(18 \mathrm{~m}^{3} \text { per } \mathrm{kg}\right) \\
\text { A fraction of } \mathrm{CH}_{4} \text { produced was } 64 \% \\
\text { Mole fraction of } \mathrm{CH}_{4} \text { in dry biogas was } 64 \% \\
\text { The volume of } \mathrm{CO}_{2} \text { was } 66,400 \mathrm{~L} \text { per } \mathrm{kg}\left(66.4 \mathrm{~m}^{3} \text { per } \mathrm{kg}\right) \\
\text { The volume of biogas produced was } 185,000 \mathrm{~L} \text { per } \mathrm{kg}\left(185 \mathrm{~m}^{3} \text { per } \mathrm{kg}\right)\end{array}$ \\
\hline
\end{tabular}

Table 7. Results of Simulation 2 from CFW.

\begin{tabular}{|c|c|c|c|c|c|c|}
\hline Input & $\begin{array}{l}\text { Quantity } \\
\text { (kg) }\end{array}$ & $\begin{array}{l}\text { Macromolecular } \\
\text { composition } \\
(\% \mathrm{DM})\end{array}$ & $\begin{array}{c}\text { Substrate } \\
\text { degradability } \\
\text { (\%) }\end{array}$ & $\begin{array}{c}\text { The temperature } \\
\text { in the digester } \\
\text { with HRT of } \\
40 \text { days }\end{array}$ & $\begin{array}{l}\mathrm{pH} \text { in the } \\
\text { digester }\end{array}$ & Output \\
\hline CFW & 60 & $\begin{array}{c}\text { Carbohydrates } 45 \% \\
\text { Ash } 0 \% \\
\text { Lipids } 40 \% \\
\text { Protein } 15 \%\end{array}$ & o & $55^{\circ} \mathrm{C}$ & T & $\begin{array}{l}\text { The standardized volume of } \mathrm{CH}_{4} \text { was } 36,300 \mathrm{~L} \text { per } \mathrm{kg}\left(36.3 \mathrm{~m}^{3} \text { per } \mathrm{kg}\right) \\
\text { A fraction of } \mathrm{CH}_{4} \text { produced was } 61.6 \% \\
\text { Mole fraction of } \mathrm{CH}_{4} \text { in dry biogas was } 61.6 \% \\
\text { The volume of } \mathrm{CO}_{2} \text { was } 22,600 \mathrm{~L} \text { per } \mathrm{kg}\left(22.6 \mathrm{~m}^{3} / \mathrm{kg}\right) \\
\text { The volume of biogas produced was } 58,900 \mathrm{~L} \text { per } \mathrm{kg}\left(58.9 \mathrm{~m}^{3} \text { per } \mathrm{kg}\right)\end{array}$ \\
\hline
\end{tabular}


Table 8. Results of Simulation 3 from co-digestion of HW and CFW.

\begin{tabular}{|c|c|c|c|c|c|c|}
\hline Input & $\begin{array}{l}\text { Quantity } \\
\text { (kg) }\end{array}$ & $\begin{array}{l}\text { Macromolecular } \\
\text { composition } \\
(\% \mathrm{DM})\end{array}$ & $\begin{array}{c}\text { Substrate } \\
\text { degradability } \\
(\%)\end{array}$ & $\begin{array}{l}\text { The temperature } \\
\text { in the reactor } \\
\text { with HRT of } \\
40 \text { days }\end{array}$ & $\begin{array}{l}\mathrm{pH} \text { in the } \\
\text { reactor }\end{array}$ & Output \\
\hline $\begin{array}{l}\mathrm{HW}+ \\
\text { CFW }\end{array}$ & 346 & $\begin{array}{c}\text { Carbohydrates } 56 \% \\
\text { Ash } 15 \% \\
\text { Lipids } 30 \% \\
\text { Protein } 18 \%\end{array}$ & 6 & $55^{\circ} \mathrm{C}$ & 7.5 & $\begin{array}{l}\text { The standardized volume of } \mathrm{CH}_{4} 157,000 \mathrm{~L} \text { per } \mathrm{kg}\left(157 \mathrm{~m}^{3} \text { per } \mathrm{kg}\right) \\
\text { The fraction of } \mathrm{CH}_{4} \text { produced } 59 \% \text {, } \\
\text { Mole fraction of } \mathrm{CH}_{4} \text { in dry biogas } 59 \% \\
\text { The volume of } \mathrm{CO}_{2} 109,000 \mathrm{~m}^{3} \text { per } \mathrm{kg}\left(109 \mathrm{~m}^{3} \text { per } \mathrm{kg}\right) \\
\text { The volume of biogas produced } 265,000 \mathrm{~L} \text { per } \mathrm{kg}\left(265 \mathrm{~m}^{3} \text { per } \mathrm{kg}\right)\end{array}$ \\
\hline
\end{tabular}

As described from the above tables, in simulation 1, the macromolecular composition of $\mathrm{HW}$ is $11 \%, 15 \%, 15 \%$, and $3 \%$ for carbohydrates, Ash, Lipids, and Protein respectively. The total volume of biogas produced was $185,000 \mathrm{~L}$ per $\mathrm{kg}\left(185 \mathrm{~m}^{3}\right.$ per $\left.\mathrm{kg}\right)$ from which the amount of $\mathrm{CH}_{4}$ produced was $118,000 \mathrm{~L}$ per $\mathrm{kg}\left(118 \mathrm{~m}^{3}\right.$ per $\left.\mathrm{kg}\right)$ representing $64 \% \mathrm{CH}_{4}$ from the total biogas produced. The amount of $\mathrm{CO}_{2}$ produced was $66,400 \mathrm{~L}$ per $\mathrm{kg}\left(66.4 \mathrm{~m}^{3}\right.$ per $\left.\mathrm{kg}\right)$ representing $35.9 \%$ of the total gas produced. In simulation 2 , the macromolecular composition of CFW is $45 \%, 0 \%, 40 \%$, and $15 \%$ for carbohydrates, Ash, Lipids, and Protein respectively. The total volume of biogas produced was $58,900 \mathrm{~L}$ per $\mathrm{kg}(58.9$ $\mathrm{m}^{3}$ per $\mathrm{kg}$ ) from which the amount of $\mathrm{CH}_{4}$ produced was $36,300 \mathrm{~L}$ per $\mathrm{kg}(36.3$ $\mathrm{m}^{3}$ per $\mathrm{kg}$ ) representing $61.6 \% \mathrm{CH}_{4}$ from the total gas produced. The amount of $\mathrm{CO}_{2}$ produced was $22,600 \mathrm{~L}$ per $\mathrm{kg}\left(22.6 \mathrm{~m}^{3}\right.$ per $\left.\mathrm{kg}\right)$ representing $38.4 \%$ of the total biogas produced. In simulation 3 , the macromolecular composition of the mixture was $56 \%, 15 \%, 30 \%$, and $18 \%$ for carbohydrates, Ash, Lipids, and Protein respectively. The biogas production from co-digestion was high compared to $\mathrm{HW}$ and $\mathrm{CFW}$ digestion alone. However, the $\% \mathrm{CH}_{4}$ was low compared to them. The total volume of biogas produced was $265,000 \mathrm{~L}$ per $\mathrm{kg}\left(265 \mathrm{~m}^{3}\right.$ per $\left.\mathrm{kg}\right)$ from which the amount of $\mathrm{CH}_{4}$ produced was $157,000 \mathrm{~L}$ per $\mathrm{kg}\left(157 \mathrm{~m}^{3}\right.$ per $\left.\mathrm{kg}\right)$ representing $59 \% \mathrm{CH}_{4}$ from the total gas produced. The amount of $\mathrm{CO}_{2}$ produced was $109,000 \mathrm{~L}$ per $\mathrm{kg}\left(109 \mathrm{~m}^{3}\right.$ per $\mathrm{kg}$ ) representing $41 \%$ of the total biogas produced. All digesters presented high degradability with $90 \%$.

\subsection{Graphical Presentation and Analysis of the Results}

Figure 6 and Figure 7 show pie charts and bar charts for the mole fraction of methane in dry biogas produced from co-digestion of HW and CFW.

The two graphs above show that single digestion of HW and CFW gives results of $64 \%$ and $61.6 \%$ respectively. When the two types of wastes are co-digested, they also give a fairly good result of 59\%; a figure which is within the bracket of $55 \%-65 \% \mathrm{CH}_{4}$ composition [30] [32]. From the simulation results 1 and 2, it can be seen that both substrates (HW and CFW) have the potential of producing enough biogas, with gas constituent compositions well comparable [33] [34]. Similarly, if the two substrates are co-digested, it can also be seen that enough $\mathrm{CH}_{4}$ is well comparable to the constituent compositions presented by [32] [35]. 


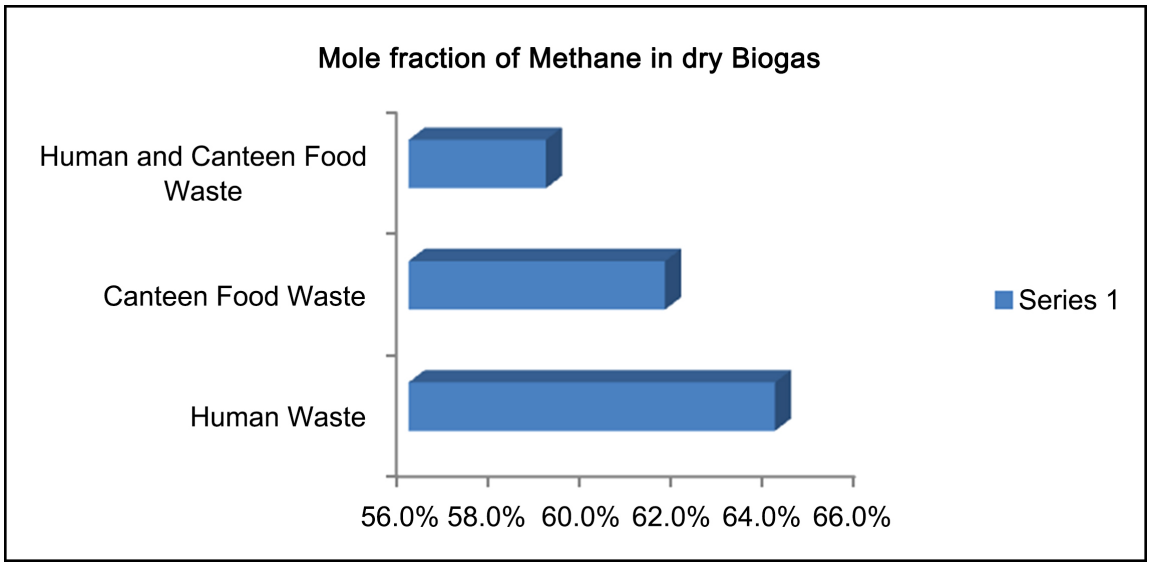

Figure 6. Bar chart showing Mole fraction of Methane in dry biogas.

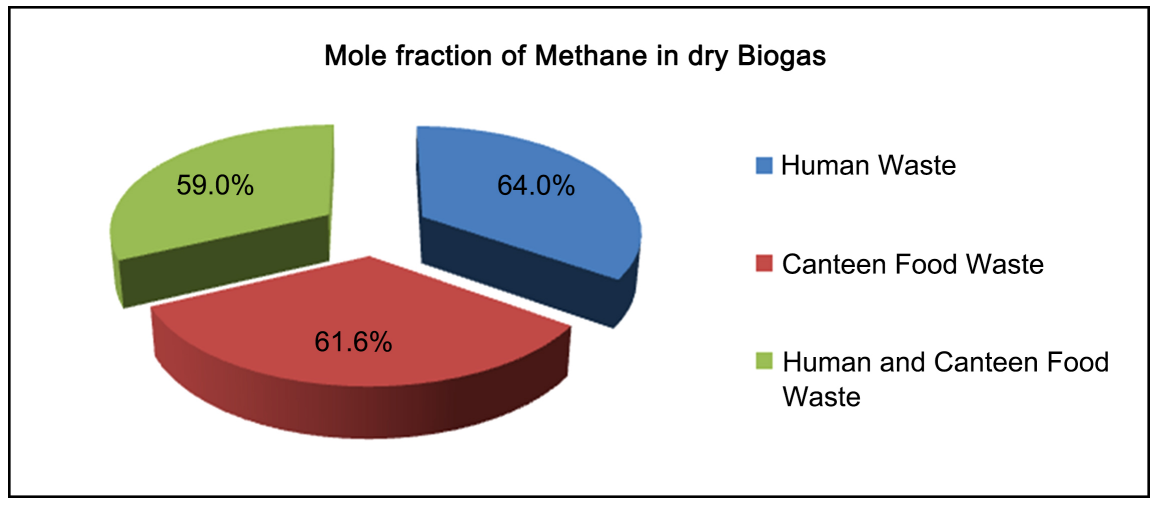

Figure 7. Pie chart showing Mole fraction of Methane in dry biogas.

The study [36] reported that the quantity and quality of biogas produced from biodegradable wastes largely depend on the nature and composition of the digester feedstock, temperature, organic loading rate, HRT, and C/N ratio. Proper management of the production process is also of great importance. This simulation exercise did not show the $\mathrm{C} / \mathrm{N}$ ratio. In general, anaerobic microbes utilize carbon 25 - 30 times faster than nitrogen. So for efficient biogas production, the $\mathrm{C} / \mathrm{N}$ ratio in the feedstock should be maintained at 20 - 30:1 [9] [37] [38]. This is the optimal value that can give out enough $\mathrm{CH}_{4}$ gas. However, the designer of this study will use rice straw/bran to improve the $\mathrm{C} / \mathrm{N}$ ratio during the anaerobic co-digestion of these wastes. Plants such as rice straw have a high percentage of carbon. For example, rice straw has a $\mathrm{C} / \mathrm{N}$ ratio of 70:1 [39] such that it can be mixed with materials of low $\mathrm{C} / \mathrm{N}$ ratio such as $\mathrm{HW}$ to maintain this optimum $\mathrm{C} / \mathrm{N}$ ratio thereby increasing the $\mathrm{CH}_{4}$ yield.

In the study of co-digestion of food waste and human excreta for biogas production [40], the value of biogas generated from a 40-liter laboratory-scale $\mathrm{AD}$ was $84,750 \mathrm{~cm}^{3}\left(0.08475 \mathrm{~m}^{3}\right)$ comprising $58 \% \mathrm{CH}_{4}$ and $24 \% \mathrm{CO}_{2}$ with a mesophilic temperature range of $22^{\circ} \mathrm{C}-30.5^{\circ} \mathrm{C}$ throughout the study. The simulated results of this design study obtained a $\mathrm{CH}_{4}$ value of $59 \%$ which is slightly higher than what was found in this laboratory experiment. However, it was argued that 
if a higher temperature, in this case, $50^{\circ} \mathrm{C}-60^{\circ} \mathrm{C}$ was reached during the $\mathrm{AD}$ process a higher percentage value of $\mathrm{CH}_{4}$ yield would have been maintained because methane methanogenic bacteria which is responsible for $\mathrm{CH}_{4}$ production work efficiently at a mesophilic temperature of $30^{\circ} \mathrm{C}-40^{\circ} \mathrm{C}$ and thermophilic temperature of $50^{\circ} \mathrm{C}-60^{\circ} \mathrm{C}$.

The study suggested the temperature of below $30^{\circ} \mathrm{C}$ slowed the development of methanogenic bacteria responsible for $\mathrm{CH}_{4}$ production, hence low yield. In the study of [41] which was done to find out the yield of $\mathrm{CH}_{4}$ when fruit vegetable waste and food wastes were digested separately in anaerobic conditions, methane yields for fruit vegetable waste and food waste in $\mathrm{m}^{3}$ per $\mathrm{kg}$-VS were $35 \%$ and $60 \%$ respectively. This shows that there is potential in food wastes for $\mathrm{CH} 4$ production. The results are also very comparable with the value obtained through simulation of biogas production in CFW (61.6\%). A study of [42] reported that with a proper organic loading rate into the biodigester, the highest $\mathrm{CH}_{4}$ production yield was $64 \%$. Therefore, the simulation results of this design agree with those of this study. In the study of [18], a biodigester of volume 2.5 $\mathrm{m}^{3}$, gasometer volume of $0.7 \mathrm{~m}^{3}$, and digestate volume of $2.5 \mathrm{~m}^{3}$ were designed. With an HRT of 30 days, the total gas produced was $0.6108 \mathrm{~m}^{3}$, with maximum gas production of $0.037 \mathrm{~m}^{3}$ per day while the maximum biogas potential was $0.771 \mathrm{~m}^{3}$. This study has designed a biogas of volume $62 \mathrm{~m}^{3}$. Mathematically it can be proved that if a $2.5 \mathrm{~m}^{3}$ biodigester produces $0.037 \mathrm{~m}^{3}$ per day of biogas, then a $61 \mathrm{~m}^{3}$ biodigester will produce

$$
(0.037 \div 2.5) \mathrm{m}^{3} \times 62 / \text { day }=0.9176 \mathrm{~m}^{3} \text { per day of biogas }
$$

We can assume that with an HRT of 40 days as per this design, the volume of biogas produced in the digester will be more than $0.9176 \mathrm{~m}^{3}$ per day. Taking this value of $0.9176 \mathrm{~m}^{3}$ per day of biogas production, it means that to satisfy the demand of biogas at Phalombe secondary school which is currently at $42.85 \mathrm{~m}^{3}$ per day as per the researcher's calculations, then this demand will be met within 47 days. But this is when the HRT is 30 days. Therefore, with an HRT of 40 days as per this design and the addition of rice straw to the substrate to improve the $\mathrm{C} / \mathrm{N}$ ratio, then the demand can be met in less than 47 days. Therefore, this is a viable design. It must also be mentioned here that proper management of the whole biogas production process is very vital to achieve good results. Table 9 shows standard sizes (models) of fixed dome biogas plants used in Bangladesh.

According to Table 9 from these articles, we can compare the effective digester volumes and their respective rated biogas production with the new design. It can be seen that if a digester of volume $11.8 \mathrm{~m}^{3}$ produces $4.8 \mathrm{~m}^{3}$ of biogas per day, then from the new design of $62 \mathrm{~m}^{3}$ digester we can get:

$$
4.8 \mathrm{~m}^{3} \text { per day } \times(62 \div 11.8)=25.2 \mathrm{~m}^{3} \text { per day of biogas }
$$

The energy demand at Phalombe Boarding School is found to be $42.85 \mathrm{~m}^{3}$ per day. So at the rate of $25.2 \mathrm{~m}^{3}$ per day of biogas, this demand can be meet within a very short period. 


\subsection{Use of Conversion Factors for Biogas}

If we use conversion factors in Figure 8 we can calculate $\mathrm{CH}_{4}$ production from the biogas energy demand in this design.

From the table in Figure $8,1 \mathrm{~m}^{3}$ of biogas $=0.65 \mathrm{~m}^{3}$ of $\mathrm{CH}_{4}$. Therefore the $25.2 \mathrm{~m}^{3}$ per day of biogas, $\mathrm{CH}_{4}$ produced will be $0.65 \mathrm{~m}^{3} \times 25.2 \mathrm{~m}^{3}$ per day $=$ $16.38 \mathrm{~m}^{3}$ per day

From this value, it can be assumed that meeting the demand of $42.85 \mathrm{~m}^{3}$ per day can be achieved in 3 days after the HRT which in this design is 40 days. A study [45] proved that the best HRT is below 44 days because after this day biogas production becomes stable for some time and then drops. Also, studies [23] [25] showed the same effect of HRT. So, an HRT of 40 days for this design is a good time for digestion since by the time this day is reached production of biogas will be at its peak and the yield will be stable from the $44^{\text {th }}$ day.Using the value of $25.2 \mathrm{~m}^{3}$ per day of dry biogas, the Mole fraction of $\mathrm{CH}_{4}$ in dry biogas can be calculated as follows:

Amount of dry biogas production per day $=25.2 \mathrm{~m}^{3}$.

Amount of Methane production per day $=16.38 \mathrm{~m}^{3}$.

Then the Mole fraction of $\mathrm{CH}_{4}$ in dry biogas will be $(16.38 \div 25.2) \times 100 \%=65 \%$.

This value of the mole fraction of $\mathrm{CH}_{4}$ is approximately the same as the values found in the simulation results. Therefore, the volume of this biogas plant designed in this study will be able to meet energy demand at Phalombe Boarding Secondary school.

Table 9. Standard sizes of fixed dome biogas plants used in Bangladesh.

\begin{tabular}{ccc}
\hline & \multicolumn{2}{c}{ Biogas plants used in Bangladesh } \\
\hline $\begin{array}{c}\text { Rated biogas production } \\
\left(\mathrm{m}^{3} / \text { day }\right)\end{array}$ & \multicolumn{2}{c}{ Effective digester volume $\left(\mathrm{m}^{3}\right)$} \\
\cline { 2 - 3 } 1.2 & 3.0 & Poultry \\
1.6 & 3.8 & 2.3 \\
2.0 & 4.8 & 3.0 \\
2.4 & 5.8 & 3.9 \\
3.2 & 7.8 & 4.5 \\
4.8 & 11.8 & 6.0 \\
\hline
\end{tabular}

Source: study Article [43] [44].

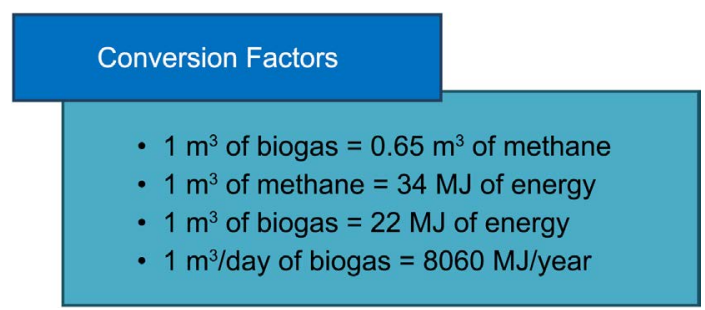

Figure 8. Conversion factors for Biogas [43]. 


\subsection{Economic Viability of the Design}

Initial investment costs for a fixed dome biogas digester may seem to be high. However, it has more advantages than the other types of biogas plants namely. The amount of firewood used by Phalombe Secondary school per term is 60 tons. In three terms it uses 180 tons of firewood. One ton costs US\$16.67. Therefore 180 tons cost US $\$ 3000$. The school spends US $\$ 344$ on electricity per month. A school term is approximately 4 months. This means that the school spends a total of US\$1032 per term. The school has three academic terms, so the total amount of money spent on electricity in one academic year is approximately US $\$ 3096$.

If these two expenditures are summed up (firewood plus electricity), the total expenditure in one academic year is approximately US\$6096. The cost of installing a biogas plant at the school is approximately US\$5277.57. This amount is less than the amount of money the school spends on firewood only in one academic year and it can be used to construct the biogas plant at the school. Therefore, the use of a biogas plant will not only curb deforestation in the district but also make great savings on the money the school is currently spending on firewood and electricity. This money can be used for other school requirements. Moreover, according to the Indian Agriculture Research Institute (ICAR), a single biogas plant with a capacity of $2.8 \mathrm{~m}^{3}$ can save a woodland area of 0.12 ha per year. Therefore, with this designed biogas plant whose capacity is $62 \mathrm{~m}^{3}$, it can save a forest area of 2.66 ha of woodland per year in the Phalombe district.

\section{Conclusion}

This research study has reviewed the common types of biogas plants that are used worldwide. There are several factors to be looked into when designing the type of biodigester to be used in a particular area. The choice of the right biodigester to be used in a particular area is of crucial importance when designing biogas plants. The design stage should take into consideration very important factors such as the type of substrate to be used, the continued availability of the substrate, availability of low-cost construction materials, the shape of the biodigester, weather conditions of the area where the biogas plant is going to be installed, the life span of the biogas plant which depends on the quality of the materials used in the construction and masonry skills. The results of this study have shown that human and canteen food wastes are good substrates to be co-digested in a biodigester to produce biogas which can be used for cooking and lighting hence the need to promote co-digestion biogas technology. In Malawi, there are no recycling technologies that can convert these wastes to something that does not pose health risks to humans once the wastes are disposed of. The use of clean technologies such as biogas for cooking and heating has been undermined by most developing countries. According to 2018 World Health Organization (WHO) report 3.8 million people, a year die prematurely from illness attributed to household air pollution which is caused by the inefficient use 
of solid fuels such as firewood crop wastes, charcoal, coal, and kerosene in open fires for cooking and heating. Therefore, this premature death could be avoided if the use of methane gas for cooking is encouraged and adapted by governments because it is a clean, cheap, and renewable source of energy.

\section{Acknowledgements}

The authors acknowledge the support from the African Centre of Excellence in Energy for Sustainable Development (ACE-ESD), University of Rwanda, College of Science and Technology (CST), Rwanda, and Malawi University of Science and Technology (MUST), Limbe, Malawi which made this research a success.

\section{Funding}

This research was financially supported by the World Bank and the Inter-University Council of East Africa (IUCEA) through the African Centre of Excellence in Energy for Sustainable Development (ACE-ESD) hosted at the University of Rwanda, College of Science and Technology (CST), Rwanda and Malawi University of Science and Technology (MUST), Limbe, Malawi. The support was awarded to NYIRENDA Austin Kawelamzenje. The funders, however, had no role in study design, data collection and analysis, preparation of the manuscript, and/or the decision to publish.

\section{Competing Interests}

Authors have declared that no competing interests exist.

\section{References}

[1] Chagunda, M.M.G., Roberts, D.J., Chitawo, M.L. and Kasulo, V. (2009) Biogas Project in Malawi Leads to Other Benefits Bioenergy.

[2] Malawi Country Report World Bank (2019) Country Environmental Analysis.

[3] Adoniya Ben, S.K.J.G. and John, L.T. (2015) Energy Supply in Malawi-Options and Issues. Journal of Energy in Southern Africa, 26, 19-32. https://doi.org/10.17159/2413-3051/2015/v26i2a2192

[4] Ramaraj, Y.U. (2016) Effect of Temperature on the Performance of Biogas Production from Duckweed. Chemistry Research Journal, 1, 58-66.

[5] Awotiwon, M.O. (2007) Production of Biogas from Banana and Plant Peels. Advances in Environmental Biology, 1, 33-38.

[6] Mamphweli, G.M.S. and Mukumba, P. (2016) Batch Anaerobic Co-Digestion of Cow Dung and Donkey Manure. South African Journal of Science, 112, 1-4.

[7] Adhikari, R.S.S.K., Sims, R.E.H., Hasslet, S. and Murray, P. (2015) Improvement of Biogas Production Efficiency through Co-Digestion Cattle Dung with Crop Residues. Case Study: Nepal. Ninth International Conference on Sensing Technology, Auckland, 8-10 December 2015, 803-810. https://doi.org/10.1109/ICSensT.2015.7438507

[8] Ngan, N.V.C., Chan, F.M.S.., Nam, T.S., Huynh, V.T., Maguyon-Detras, M.C., Hung, D.V., Cuong, D.M. and Hung, N.V. (2020) Anaerobic Digestion of Rice Straw for Biogas Production. Sustainable Rice Straw Management. 
[9] Twizerimana, M., Marimi, M., Bura, X. and Nganyi, E.O. (2020) Biogas Production from Co-Digestion of Cotton Yarn Waste and Human Urine. Journal of Energy Research and Reviews, 6, 20-29. https://doi.org/10.9734/jenrr/2020/v6i130158

[10] Zhang, R. and Zhang, Z. (1999) Biogasification of Rice Straw with an Anaerobic-Phased Solids Digester System. Bioresource Technology, 68, 235-245. https://doi.org/10.1016/S0960-8524(98)00154-0

[11] Gummert, M., Van Hung, N., Chivenge, P. and Douthwaite, B. (2020) Sustainable Rice Straw Management. Springer, Berlin. https://doi.org/10.1007/978-3-030-32373-8

[12] Ramatsa, I.M., Akinlabi, E.T., Madyira, D.M. and Huberts, R. (2014) Design of the Bio-Digester for Biogas Production: A Review. Proceedings of the World Congress on Engineering and Computer Science, Vol. 2, San Francisco, 22-24 October 2014, 628-631.

[13] Eckerwall, V., Larsson, M. and Jansson, C. (2015) Development and Testing of Biogas Technology in Malawi to Reduce Deforestation and Support Climate Change Mitigation and Adaptation.

[14] Regattieri, A., Bortolini, M., Ferrari, E., Gamberi, M. and Piana, F. (2018) Biogas Micro-Production from Human Organic Waste-A Research Proposal. Sustainability, 10, 330. https://doi.org/10.3390/su10020330

[15] Peter, M.K., Alfa, M.I., Datau, G., Aluwong, K.C. and Hadi, M.I. (2017) Design, Development and Performance Evaluation of an Anaerobic Plant. American Journal of Engineering Research, 6, 28-33.

[16] Briefs, O.T. (2012) Design, Construction, and Maintenance of a Biogas Generator. $1-23$.

[17] Orgur, M.S. and Mbatia, E.O. (2013) Conversion of Kitchen Waste to Biogas. International Journal of Engineering Science, 2, 70-76.

[18] Alfa, M.I., Wamyil, F.B., Daffi, R.E. and Igboro, S.B. (2017) Design, Development and Evaluation of Slaughterhouse Anaerobic Digestion Plant Model. American Journal of Engineering Research, 6, 70-74.

[19] Ogur, E.O. and Irungu, P. (2013) Design of a Biogas Generator. International Journal of Engineering Research and Applications, 3, 630-635.

[20] Dueñas-Berra, L.Y., Artiles-López, D.M., Hofbauer, A.M., Santiago-Azpiazu, G.C. and Morales-Hernández, J.L. (2015) Design Guide for Biodigester Treatment Plant in Cowshed Housing. ECORFAN.

[21] Hoerz, T., Krämer, P., Klingler, B., Kellner, C., Wittur, T., Klopotek, F.V., Krieg, A. and Euler, H. (1998) Biogas Digest II.

[22] Ali, M.F. and Islam, R. (2014) Designing Human and Kitchen Waste Based Biogas \& Solar Plant for Pabna University of Science \& Technology (PUST) Campus and Cost-Benefit Analysis after Renewable Energy Interconnection on PUST Campus's Grid Network. 28-34.

[23] Chen, X.G.A., Adl, M., Sheng, K.C. and Xia, Y.H. (2012) Examining a Hybrid Plug-Flow Pilot Reactor for Anaerobic Digestion of Farm-Based Biodegradable Solids. International Journal of Environment, 6, 335-344.

[24] Kossmann, W. (1999) Biogas Digest: Biogas—Costs and Benefits and Biogas—Programme Implementation III.

[25] Angelikadi, B.K. (2009) Serial CSTR Digester Configuration for Improving Biogas Production from Manure. Water Research, 43, 166-172.

https://doi.org/10.1016/j.watres.2008.09.041 
[26] Omer, A.M. (2016) An Overview of Biomass and Biogas for Energy Generation: Recent Development and Perspectives. Advanced Materials. TechConnect Briefs, 2, 122-125. https://doi.org/10.31248/JBBD2016.010

[27] Deng, L., Liu, Y., Wang, W., Deng, L., Liu, Y. and Wang, W. (2020) Biogas Plant. In: Deng, L.W., Liu, Y. and Wang, W.G., Eds., Biogas Technology, Springer, Berlin, 109-156. https://doi.org/10.1007/978-981-15-4940-3 4

[28] Rwanda Standard Board (2016) Domestic Biogas Plant-Design, Construction and Operation Code of Practice (DRS 306:2016). Kigali.

[29] Hafner, S.D., Koch, K., Carrere, H., Astals, S., Weinrich, S. and Rennuit, C. (2018) Software for Biogas Research: Tools for Measurement and Prediction of Methane Production. SoftwareX, 7, 205-210. https://doi.org/10.1016/j.softx.2018.06.005

[30] Snakya, V. and Kalia, S.V. (2000) Anaerobic Digestion of Banana Stem Waste. Bioresource Technology, 73, 191-193. https://doi.org/10.1016/S0960-8524(99)00172-8

[31] Edwin, M. and Joseph, S.S. (2015) Design Considerations of Anaerobic Digester for Producing Biogas Loaded with Cow Manure. International Journal of Applied Engineering Research, 10, 365-372.

[32] Zheng, Y., Zhao, J., Xu, F. and Li, Y. (2014) Pretreatment of Lignocellulosic Biomass for Enhanced Biogas Production. Progress in Energy and Combustion Science, 42, 35-53. https://doi.org/10.1016/j.pecs.2014.01.001

[33] Tumutegyereize, P., Ketlogetswe, C., Gandure, J. and Banadda, N. (2016) Effect of Variation in Co-Digestion Ratios of Matooke, Cassava, and Sweet Potato Peels on Hydraulic Retention Time, Methane Yield and Its Kinetics. Journal of Sustainable Bioenergy Systems, 6, 93-115. https://doi.org/10.4236/jsbs.2016.64009

[34] Tran, K.C. (2017) Anaerobic Digestion of Microalgal Biomass: Effects of Solid Concentration and Pre-Treatment. Final Thesis, University of Southampton, Nusajaya.

[35] Kheiredine, B., Derbal, K. and Bencheikh-Lehocine, M. (2014) Effect of Starting ph on the Produced Methane from Dairy Wastewater in Thermophilic Phase. Chemical Engineering Transactions, 38, 511-516.

[36] Madyira, E.T.A.D.M., Huberts, R. and Ramatsa, I.M. (2014) Design of the Bio-Digester for Biogas Production: A Review. Proceedings of the World Congress on Engineering and Computer Science, San Francisco, 22-24 October 2014, 1-5.

[37] Gashaw, A. (2014) Anaerobic Co-Digestion of Biodegradable Municipal Solid Waste with Human Excreta for Biogas Production: A Review. American Journal of Applied Chemistry, 2, 55-62. https://doi.org/10.11648/j.ajac.20140204.12

[38] Guarino, G., Carotenuto, C., Di Cristofaro, F., Papa, S., Morrone, B. and Minale, M. (2016) Does the C/N Ratio Affect the Bio-Methane Yield? A Three Years Investigation of Buffalo Manure Digestion. Chemical Engineering Transactions, 49, 463-468.

[39] Naik, L., Gebreegziabher, Z., Tumwesige, V., Balana, B., Mwirigi, J. and Austin, G. (2014) Factors Determining the Stability and Productivity of Small-Scale Anaerobic Digesters. Biomass and Bioenergy, 70, 51-57.

[40] Oramusi, U.S. and Dahunsi, S.O. (2013) Co-Digestion of Food Waste and Human Excreta for Biogas Production. British Biotechnology, 3, 485-499. https://doi.org/10.9734/BBJ/2013/4476

[41] Malikanthi, T.J.J., Ruchira, A. and Senayake, N.S. (2015) Anaerobic Digestion of Food and Market Waste; Waste Characterization and Biomethane Potential: A Case Study in Sri Lanka. SLEMA Journal, 18, 29-33. https://doi.org/10.4038/slemaj.v18i2.18 
[42] Sadjere, B.G.E., Ejiroghene, K.O. and Patrick, O.E. (2017) Effect of Organic Loading Rate (OLR) on Biogas Yield Using a Single and Three-Stages Continuous Anaerobic Digestion Reactors. International Journal of Engineering Research in Africa, 39, 147-155. https://doi.org/10.4028/www.scientific.net/JERA.39.147

[43] IRENA (2016) Measuring Small-Scale Biogas Capacity and Production. International Renewable Energy Agency, 11-16.

[44] National Domestic Biogas and Manure Programme (NDBMP) (2013) BIOGAS AUDIT: Summary of Findings and Recommendations. Dhaka, Bangladesh and Beijing, China.

[45] Agus Haryanto, A., Triyono, S. and Nugroho, H.W. (2018) Effect of Hydraulic Retention Time on Biogas Production from Cow Dung in a Semi Continuous Anaerobic Digester. International Journal of Renewable Energy Development, 7, 93-100. https://doi.org/10.14710/ijred.7.2.93-100 